\title{
DETERMINATION OF THE TYPE OF TRANSMISSION SHAFT FOR A BAJA SAE PROTOTYPE FROM THE MVP METHODOLOGY
}

Leon Claudio Pereira de Santana Juniora, Luan Vitor dos Santos Torres ${ }^{a}$, Nathan Gois de Alcântara ${ }^{\text {, }}$ Thiago Rosario Souza ${ }^{a}$, Pedro Bancillon Ventin Muniza.

${ }^{a}$ Centro Universitário SENAI CIMATEC, Brazil.

\begin{abstract}
The choice of the transmission shaft must take into account some aspects, such as: Free angulation, resistance, maintenance, mass, off-road use, car stability, reliability, project application. Based on these aspects, this article presents a study about the transmission axis for a BAJA SAE prototype based on the Minimum Viable Product (MVP) methodology associated with a matrix decision. Through this analysis, it is possible to choose the transmission shaft which better suits the criteria for using the prototype to which was the shaft cardan joint.
\end{abstract}

Keywords: Transmission shaft, Prototype, Baja.

\section{DETERMINAÇÃO DO TIPO DE EIXO DE TRANSMISSÃO PARA UM PROTÓTIPO BAJA SAE A PARTIR DA METODOLOGIA MVP}

Resumo: Para escolher a determinação de um eixo de transmissão, são levados em conta vários aspectos, tal que: Angulação livre, resistência, manutenção, massa utilização off-road, estabilidade do carro, confiabilidade, aplicação no projeto. A partir desses aspectos, foi realizado no artigo a determinação de um eixo de transmissão para um protótipo BAJA SAE a partir da metodologia Minimum Viable Product $(M V P)$ associada a matriz de decisão. Com base no método de análise escolhido pela equipe, para escolher o eixo de transmissão que mais se adequa aos critérios de uso do protótipo ao qual foi o eixo com a junta cardan.

Palavras-chave: Eixo de Transmissão, Protótipo, Baja. 


\section{INTRODUCTION}

The transmission shaft is based on bringing the torque generated by the engine to a transmission system, in which that torque and speed will be modified. The purpose of this change is to intensify the forces generated by an internal combustion engine with the role of overcoming road obstacles faced by the vehicle, such as: aerodynamics, frictional force and weight. After the transmission box, torque and rotation must be conducted to the wheels by means of a transfer system. The cardan, homokinetic and rigid axles are presented in the following work [1].

The cardan has the purpose of transmitting the energy generated by the engine to the transmission shaft, which will pass to the differential and soon afterwards to the semi-axles and consequently to the wheels [2].

The CV shaft is installed with the "gearbox-engine" assembly. In certain vehicle brands, they are installed in the front wheel of the car, and in others in the rear. And it consists of the following elements: Axle tip, locking rings, clamps, hoods, semi-tree and CV joint, its main qualities are: suffer less vibrations making movement smoother and more constant, however this type of joint does not support much torque when working at an angle and has a working limit of $22^{\circ}$ [3].

In some vehicles that have the engine installed in the front and the driving wheels in the rear, a rigid axle is used, in which the differential and the semi-trees are housed. The semi-trees receive the rotation movements, coming from the differential, and transmit them to the driving wheels [4].

The survey of the characteristics of the types of transmission mentioned above allows to verify some fundamental information in the application of MVP, such as: angle of work, installation, maintenance, components, positive and negative points.

This article was carried out based on existing research on the types of transmission shafts. The motivation for making this article is to analyze crucial points for the prototype of the mini BAJA SAE from SENAI CIMATEC, using the Minimum Viable Product (MVP) technique that translated into Portuguese "Mínimo Produto Viável", being a method of verifying the functionality and validation of the product in question, having as main aspects to be observed: free or working angle, resistance and maintenance.

\section{METHODOLOGY}

To determine which models could be applied to the mini BAJA prototype, a study was carried out using the MVP methodology (Minimum Viable Product), where the basic criteria that meets the prototype was defined, the ones listed below.

Angles greater than that mentioned will not provide adequate behavior and performance of the prototype since these angulations presented a high risk of breakage, besides the suspension work does not provide a greater angulation than the established value, this angle also refers to the static vehicle where it would be at 
the highest angle. The torque was set at approximately $600 \mathrm{~N} . \mathrm{m}$, as it is the work value referring to the reduction box output established in the project.

Table 1: Basic criteria for transmission shafts

\begin{tabular}{|c|c|}
\hline \multicolumn{2}{|c|}{ Basic Criteria } \\
\hline Angle & Torque \\
\hline $0^{\circ}<25^{\circ}$ & 606,23 N.m. \\
\hline
\end{tabular}

Source: Table made by the author(s)

Based on the data in table 1, the angle and torque were determined based on the information from the current prototype, with the angle value being the maximum angulation of the axle in relation to the suspension work and the torque being the output force of the reduction box, from this analysis of criteria that can meet the project, a study was carried out to find the axes that can meet these minimum criteria, being those axes with cardan joints, homokinetic and rigid axles.

The model chosen for the shaft cardan joint was the CW 4000 model, being a conventional oval tube cardan, which in continuous working conditions should not exceed $15^{\circ}$ and can reach $35^{\circ}$ for a short period of time [5].

Figure 1: Table with information on cardans with oval tubes

\begin{tabular}{|c|c|c|c|c|}
\hline \multirow{2}{*}{ Oval tube cardan (lemon type) } \\
\cline { 2 - 5 } SERIES & \multicolumn{4}{|c|}{ WORK CAPACITY } \\
\cline { 2 - 5 } & CV 540 RPM & N.m & CV & N.m \\
\hline TW 1000 & 16 & 210 & 24 & 175 \\
\hline CW 2000 & 27 & 355 & 42 & 295 \\
\hline CW 3000 & 38 & 500 & 60 & 415 \\
\hline CW 4000 & 52 & 735 & 80 & 609 \\
\hline
\end{tabular}

Source: Aemco Products and Applications Catalog (Pg. 8)

The reason for opting for the CW 4000 is for the same reason that the basic filters are included in the intervals from $540 \mathrm{rpm}$ to $1000 \mathrm{rpm}$ (figure 1).

The choice of CV joints was based on the NJH95-1862S model, which meets the minimum requirements but limits the suspension travel and risk breaking due to the high torque demand on angle as its maximum working angle is $22^{\circ}$. [6]

For the rigid axle, the best option was the same used in vehicles of the Drift trike model, because they are resistant enough and because they do not increase the mass of the vehicle too much, besides the possibility of installing the brake directly on the axle. [7]

After finding these minimum joints that meet the prototype, a decision matrix was made to find out which of the axes will best suit, within the decision matrix some criteria were listed according to the use and application, these being free angulation, resistance, maintenance, durability, mass, off-road use, vehicle stability, reliability and application to the project.

Table 2: Transmission axis decision matrix 


\begin{tabular}{|c|c|c|c|c|c|c|c|}
\hline Points analyzed & Weight & $\begin{array}{c}\text { Cardan } \\
\text { joint }\end{array}$ & $\begin{array}{c}\text { Rigid } \\
\text { shaft }\end{array}$ & $\begin{array}{c}\text { CV } \\
\text { Joint }\end{array}$ & $\begin{array}{c}\text { Note } \mathrm{x} \text { Weight } \\
\text { (Cardan) }\end{array}$ & $\begin{array}{c}\text { Note } \mathrm{x} \text { Weight } \\
\text { (Rigid shaft) }\end{array}$ & $\begin{array}{c}\text { Note } \mathrm{x} \text { Weight } \\
\text { (CV Joint) }\end{array}$ \\
\hline Free angle & 4 & 100 & 20 & 100 & 400 & 80 & 400 \\
\hline Resistance & 5 & 80 & 90 & 60 & 400 & 450 & 300 \\
\hline Maintenance & 4 & 70 & 80 & 50 & 280 & 320 & 200 \\
\hline Mass & 4 & 50 & 80 & 70 & 200 & 320 & 280 \\
\hline Use off road & 5 & 80 & 80 & 60 & 400 & 400 & 300 \\
\hline Car stability & 3 & 70 & 50 & 70 & 210 & 150 & 210 \\
\hline $\begin{array}{c}\text { Reliability } \\
\text { Application to the }\end{array}$ & 5 & 80 & 80 & 60 & 400 & 400 & 300 \\
\hline
\end{tabular}

Source: Table made by the author(s)

The points analyzed for the construction of the decision matrix are linked to the use of the vehicle in competitions held by SAE, being this use in extreme work situations.

Free angulation - refers to the angles of freedom of the joints, this mainly related to the gimbal and homokinetic, because it directly influences the work of the suspension and height of the vehicle;

Resistance - refers to the ability to withstand obstacles in their use in competitions;

Maintenance - refers to the amount of attention and maintenance that it will need to operate in the best way;

Mass - refers to the amount of mass of each axis, the lower the mass the better the performance of the prototype;

Off-road use - in view of the use of the vehicle in off-road competitions, this item refers to the use of the same axle normally by vehicles with similar proposals;

Vehicle stability - refers to the stability that the axle will be able to pass to the vehicle;

Project application - Refers to the ease of implementation in the prototype project.

From the analysis of the decision matrix we can see that in some aspects some of the axes stand out more than the others, this difference being mainly due to their construction differences.

\section{RESULTS AND DISCUSSIONS}

From the definition of the main points analyzed, a sum of all the scores for each axis was carried out, thus reaching a result of the type of axis to fit the project, as shown in the table below.

Table 3: Sum of the score obtained in the decision matrix

\begin{tabular}{|c|c|c|}
\hline \multicolumn{3}{|c|}{ Sum of punctuation per axis } \\
\hline Cardan joint & Rigid shaft & CV Joint \\
\hline 2790 & 2420 & 2490 \\
\hline
\end{tabular}

Source: Table made by the author(s)

As shown in the table above, the best axle at the points analyzed was the cardan axle, it has very important characteristics mainly in terms of durability and maintenance, which will hardly need maintenance in its use, mainly because it is a 
competitive vehicle where it will not be used often, in addition to the use in off road competitions such as Baja competitions, where there is a lot of mud and dust that would hinder and reduce the life of an axle that needs intense lubrication such as case of $\mathrm{CV}$ joints.

\section{FINAL CONSIDERATIONS}

From the work using the MVP methodology and decision matrix, we came to the conclusion that the use of the cardan shaft becomes more viable to the project, as well as used in previous prototypes of the team. In addition, we reached a more concrete conclusion about the use of it compared to other types of axis, Especially because it is possible to use it at larger working angles and also because its resistance is the most suitable for the prototype

\section{REFERENCES}

${ }^{1}$ BOSCH. AUTOMOTIVE HANDBOOK. 1. ed. [S.I.: s.n.], 2008. p. 845-845, p 1391.

2 WEIHERMANN, Henrique Weber. ESTUDO SOBRE APLICAÇÃO DE TRANSMISSÃO CONTINUAMENTE VARIÁVEL PARA VEÍCULOS DE PEQUENO PORTE. 2015. 51 p. Trabalho de conclusão de curso (ENGENHEIRO AUTOMOTIVO) - UNIVERSIDADE FEDERAL DE SANTA CATARINA CAMPUS JOINVILLE, Joinville-SC, 2015.

${ }^{3}$ ARNALDO, Felipe Muniz; ANTUNES, R. D. S; CASARIM, Eduardo. ANÁLISE dO SEMIEIXO HOMOCINÉTICO UTILIZADO NO VEÍCULO BAJA DA EQUIPE CLARENGEX E PROPOSTA DE MELHORIA PARA O SISTEMA. LINGUAGEM ACADÊMICA, Rio Claro - SP, v. 6, n. 1, p. 27-44, jun./2016. Available

in: http://www.claretianobt.com.br/download?caminho=/upload/cms/revista/sumarios/411.pdf\&arquivo=su mario2.pdf. Access in: 25 july. 2020.

${ }^{4}$ COSTA, Paulo G.. A BíBLIA DO CARRO . 1. ed. [S.I.: s.n.], 2002. p. 116-124.

5 AEMCO. AEMCO CATALOGO DE PRODUTOS E APLICAÇÕES. Versão digital: [s. n.], 2020. 106

p. Available in: https://document.onl/business/aemco-catalogo-de-produtos-e-aplicacoes.html. Access in: 18 jul. 2020. p. 8-11

- NAKATA. SEMI EIXO HOMOCINÉtICO - NJH95-1862S. Available in: https://www.catalogonakata.com.br/detalhe/njh95-1862s-semi-eixo-homocinetico-4152. Access in: 25 july. 2020.

1 SILVA, Ivan Paulo et al. TRIKE DRIFT FALCON. 2016. 26 p. TRABALHO DE CONCLUSÃO DO CURSO TÉCNICO (CURSO TÉCNICO DE MANUTENÇÃO AUTOMOTIVA) - Centro Estadual de Educação Tecnológica Paula Souza, São Caetano do Sul / SP, 2016. 
ESCOLA ESTADUAL DE EDUCAÇÃO PROFISSIONAL - EEEP. SISTEMA DE TRANSMISSÃO MECÂNICA. [S. I.: s. n.], 2011. 82 p.

NAKATA. CATÁLOGO JUNTA HOMOCINÉTICA. [S. I.: s. n.], 2018. 108 p. 